\title{
Soil solarization improves soil fertility in addition to weed management in sesame under subtropical conditions of Pakistan
}

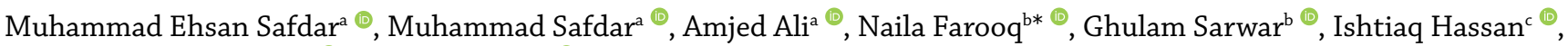 \\ Muhammad A.Nadeem ${ }^{\circledR}$, Tasawer Abbas ${ }^{c}{ }^{\circledR}$ \\ a Department of Agronomy, College of Agriculture, University of Sargodha, Sargodha, Punjab, Pakistan. ${ }^{\mathrm{b}}$ Department of Soil and Environmental Sciences, \\ College of Agriculture, University of Sargodha, Sargodha, Punjab, Pakistan. ' In-service Agriculture Training Institute Sargodha, Sargodha, Punjab, Pakistan.
}

Abstract: Background: Thermal weed control is a viable, costeffective, and eco-friendly emerging alternative to highly challenged and unsustainable chemical weed control.

Objective: To find out the most suitable pre-sowing soil solarization durations for effective weed control and soil fertility enhancement in sesame crop.

Methods: A field study was conducted during the summer season of 2016 and 2017. Different soil solarization treatments were applied, including $0,3,6,9$, and 12 weeks before sowing (WBS) of sesame by spreading transparent polythene sheets.
Results: The temperatures of solarized soil at $10 \mathrm{~cm}$ depth were $8-10^{\circ} \mathrm{C}$ more than the control. The soil NPK and organic matter contents were gradually increased with increasing solarization durations. The highest soil nitrogen (0.71\%), phosphorus (9.63 ppm), K (166.2 ppm), and organic matter content (1.12\%) were observed with the longest soil solarization for 12 WBS. Different solarization durations provided 23 to $64 \%$ weed control efficiency and up to a $34 \%$ rise in sesame yield.

Conclusions: Based on the current findings, soil solarization for 12 WBS by polythene sheets is an effective alternative to the chemical weed control method with additional positive effects on soil fertility and sesame yield.

Keywords: Thermal weed control; Non-chemical weed control; Polythene sheet

Journal Information:

ISSN - 2675-9462

Website: http://awsjournal.org

Journal of the Brazilian Weed

Science Society

How to cite: Safdar ME,

Safdar M, Ali A, Farooq N, Sarwar G,

Hassan I. et al. Soil solarization

improves soil fertility in addition

to weed management in sesame

under subtropical conditions

of Pakistan. Adv Weed Sci.

2021;39:e020219464.

https://doi.org/10.51694/AdvWeedSci/2021;39:00005

Approved by:

Editor in Chief:

Leonardo d'Antonino

Conflict of interest: The authors declare no conflict of interest regarding the publication of this manuscript.

Received: February 4, 2019

Approved: May 28, 2019

* Corresponding author: <nailafarooq90@yahoo.com>

\section{(c) (4)}

This is an open-access article distributed under the terms of the

Creative Commons Attribution License, which permits unrestricted use, distribution, and reproduction in any medium, provided that the original author and source are credited.

Copyright: 2021

\section{Introduction}

Chemical weed control, the most common weed control method worldwide, has become unsustainable due to increasing herbicide resistance and environmental concerns of herbicide use. In addition to harmful effects on human health, livestock, and natural vegetation, herbicide use is facing challenges including less accessibility to new herbicide formulation, air pollution, herbicide selectivity under changing cropping patterns and mix-cropping, unavailability of herbicide with new mode of actions, herbicide hormesis in weeds, water contamination and soil erosion (Abbas et al., 2017; Carles et al., 2017; Nadeem et al., 2017). Under the immense pressure of intensive agriculture and a changing climate in the agroecosystem, herbicides' adverse effects are not acceptable. Therefore, scientists are searching for alternate weed management strategies to provide sustainable and eco-friendly weed control in different crops.

Thermal weed control by soil solarization as a non-chemical technique will become popular due to its long-term weed control and the added benefits of increased soil nutrient availability, disease, and insect-pest management (Ghosh and Dolai, 2014). Solarization is a non-chemical process of heating the soil using polythene sheets that reduce weeds' population by decaying soil weed bank and killing weeds seedlings, and some other soil-borne pests (Stapleton and DeVay, 1986). It is more effective in warmer parts of the world and is used on a restricted but rising scale (Arbopleya, 2009; Stapleton et al., 2000). Covering wet seedbeds with transparent polythene sheets for some time captures the maximum radiation energy from sunlight and increases the top layer soil temperature to $50-60^{\circ} \mathrm{C}$ (Lamont, 2005). The upper soil layer's continuous high temperature is the main reason that decreases weed seed bank (Asagarpour et al., 2008).

Thermal weed control revealed a significant reduction in weed density and weed seed bank, and transparent plastic sheets gave better results than the dark plastic sheet (Asagarpour et al., 2008). In addition to reducing weed seed bank, selective covering of soil between the crop rows directly killed weed seedlings due to the high temperature. Kumar et al. (2002) reported that above $80 \%$ of weeds were controlled by solarization until the tomato (Solanum lycopersicum L.) harvest. Prather et al. (2002) stated that various solarization treatments were equally efficient to control weeds in strawberry, with the number of weeds reduced by $86-94 \%$ and biomass of weeds decreased by $94-99 \%$. 
In addition to weed management, soil solarization can alter soil characteristics, enhance the decomposition and mineralization of organic matter and nutrient availability; the effect of solarization on soil traits can be improved with organic matter addition (Gelsomino et al., 2006; Grunzweig et al., 1999). Unfortunately, many nutrients can get bound up with soil particles and become unavailable to the crop. Availability of these nutrients has become more critical due to the high prices of fertilizers, the effect of fertilizers on the environment, and the decrease in the natural source of nutrients. High temperatures in the root zone can help unlock these nutrients and make them available for crop plants (Yan et al., 2012). Furthermore, the increasing trend of crop residues incorporation and other organic sources of fertilizers need strategies to enhance the decomposition process. High temperatures have a significant role in increasing the decomposition process (Bothwell et al., 2014). Thus, in addition to weed control, an increase in temperature can also increase nutrient availability by unlocking the soil bonded nutrients and increasing organic matter decomposition.

Sesame (Sesamum indicum L.) is an essential oilseed crop as it is used for edible oil purposes in Indo-Pak, commonly known as the "king of oil seeds" due to its high amount of oil content (50-60\%) in the seed (Toan et al., 2010). Globally, the major sesame-producing countries are India, Uganda, Bangladesh, Pakistan, Sudan, Myanmar, Thailand, and China (Alim, 2007). Pakistan is $9^{\text {th }}$ in area and the $14^{\text {th }}$ in sesame production; this demonstrates the lower yield in Pakistan than other countries. Poor weed control is one of the primary reasons for low sesame yield in Pakistan (Ijlal et al., 2011). Weeds cause substantial yield losses in sesame under agroecological conditions of Punjab, Pakistan (Ijlal et al., 2011).

Few studies are available on thermal weed control by soil solarizations worldwide, and no research is available under agroecological conditions of Punjab, Pakistan. Therefore, this study was conducted with the following objectives: (1) to identify the effective duration of soil solarization by transparent polythene sheet under agroecological conditions of Pakistan; (2) to examine whether the thermal weed control is helpful to increase soil nutrient availability and organic carbon; and (3) to understand the effect of solarization durations on growth, yield, and yield contributing traits of sesame.

\section{Material and Methods}

\subsection{Site description}

The experiment was carried out in the research field of the Department of Agronomy, University College of Agriculture, University of Sargodha, Punjab-Pakistan during the summers of 2016 and 2017. The experimental site is categorized as subtropical semi-arid. The soil was clay loam with good drainage. The air temperature during growing seasons was between $20.3^{\circ} \mathrm{C}$ to $35.2{ }^{\circ} \mathrm{C}$, and the total precipitation was $557-564 \mathrm{~mm}$.

\subsection{Experiment design}

The experiment was arranged in a randomized block design with three replications. The treatments comprised five soil solarization with transparent polythene sheets covering the soil surface for different durations $(3,6,9$, and 12 weeks before sesame planting - var Punjab till 90). An untreated check without any weed control treatment was considered as the control. The experiment was laid out in a randomized complete block design with three replicates. The net plot size was $3 \mathrm{~m} \times 1.8 \mathrm{~m}$.

The plots were covered with polyethylene film (thickness was $75 \mu \mathrm{m}$ ) before crop sowing as pertreatment plan, and the edges of the sheet were buried in the soil to avoid the gaseous exchange. Films were placed so that there were no free air pockets inside the space between soil and polythene films. Atmospheric and soil temperature data of the treatments were recorded at weekly intervals using a digital thermometer at 10$\mathrm{cm}$ soil depth. The thermometer was inserted into films through a hole, and the temperature was measured, and then the holes were closed with scotch tape.

Pre-soaking irrigation was applied before seedbed preparation. When soil moisture reached a suitable level, the seedbed was prepared by cultivating the soil three times with a tractor-mounted cultivator, and a rotavator was run at a depth of $12 \mathrm{~cm}$. The sesame seeds were plantedin July in a single row using a manual hand drill seed at $5 \mathrm{~kg}$ of seeds per ha. Plant thinning was performed at the 4-6 leaf stage of the crop to maintain the plant-to-plant distance of $15 \mathrm{~cm}$. All other agronomic practices were kept as per standard recommendations. Nitrogen and $\mathrm{P}_{2} \mathrm{O}_{5}$ were applied at $60 \mathrm{~kg} \mathrm{ha}^{-1}$ as urea and diammonium phosphate, respectively. Plant protection measures were done to keep the crop field free from diseases and insects using Mancozeb $75 \%$ WP at the rate of $600-800 \mathrm{~g} /$ acre and Bifenthrin $10 \%$ $\mathrm{EC}$ at $600 \mathrm{~mL} / \mathrm{ha}$. The crop was manually harvested at maturity in October.

\subsection{Observations and statistical analysis}

Parameters including soil and atmospheric temperature (the morning 9:00 am and evening 4:00 pm), soil nutrients (NPK) and organic matter contents, weed growth (weed density and biomass), crop growth and yield such asplant population $\mathrm{m}^{-2}$, plant height $(\mathrm{cm})$, capsule per plant, seeds per capsule, 1,000-seeds weight (g), seed yield (ton $\mathrm{ha}^{-1}$ ), biological yield (ton ha ${ }^{-1}$ ) and harvest index were recorded. The data collected was analyzed statistically through STATISTIX 8.1" software using Fischer's analysis of variance (ANOVA) technique (Steel et al., 1997), and means were compared by Tukey's honestly significant difference (HSD) test. 


\section{Results and Discussion}

\subsection{Soil and atmospheric temperatures}

Air and soil evening temperatures during all 12 weeks of solarization remained higher than their corresponding morning temperatures (Figure 1). However, these differences were enormous for soil temperature compared to air temperature. The maximum morning $\left(37.7^{\circ} \mathrm{C}\right)$ and evening $\left(41^{\circ} \mathrm{C}\right)$ air temperatures were recorded in the $9^{\text {th }}$ and $6^{\text {th }}$ week, respectively. However, the highest morning and evening soil temperatures $\left(42.6{ }^{\circ} \mathrm{C}\right.$ and $52.7{ }^{\circ} \mathrm{C}$, respectively) were observed during the $12^{\text {th }}$ and $10^{\text {th }}$ weeks of study, respectively. The maximum rise in temperature $\left(10^{\circ} \mathrm{C}\right)$ of soil compared with non-solarized soil occurred in the $10^{\text {th }}$ week of study.

The increase in temperature in solarized plots $\left(5-10^{\circ} \mathrm{C}\right)$ occurred because of the transparent polythene sheet that captured light from the sun and trapped it inside in the form of heat, thus increasing soil temperature. These results are in agreement with those of Arora and Yaduraju (1998), Khan et al. (2012), and Sahile et al. (2005), who reported the increase in soil temperature up to $10{ }^{\circ} \mathrm{C}$ by the application of soil solarization with a transparent polythene sheet.

\subsection{Effect of solarization treatments on soil NPK contents}

The solarization treatments caused a significant increase in nitrogen $(\mathrm{N})$, phosphorus $(\mathrm{P})$, and potassium (K) of the soil (Table 1$)$. The maximum soil $\mathrm{N}(0.71 \%)$, $\mathrm{P}$ (9.63 ppm), and K (166.1 ppm) contents were recorded with soil solarization for 12 weeks before sowing, which was followed by soil solarization for nine weeks before sowing. Minimum soil N (0.47\%), P (7.42 ppm), and K (124.8 ppm) contents were noted in control plots. The increase in the soil nitrogen content by soil solarization was due to the enhanced decomposition of organic matter that released inorganic $\mathrm{N}$ in the soil. These results are in line with those of Khan et al. (2012), who reported significant differences in tomatoes' soil $\mathrm{N}$ content. Law et al. (2008) reported that soil solarization increased nitrogen availability as $\mathrm{NH}_{4}-\mathrm{N}$ and $\mathrm{NO}_{3}-\mathrm{N}$ to $\mathrm{NH}_{4}-\mathrm{N}$ released from nitrification of soil microbial biomass. Law et al. (2008) and McGovern et al. (2013) reported that soil phosphorus content rose by increasing the soil solarization duration.

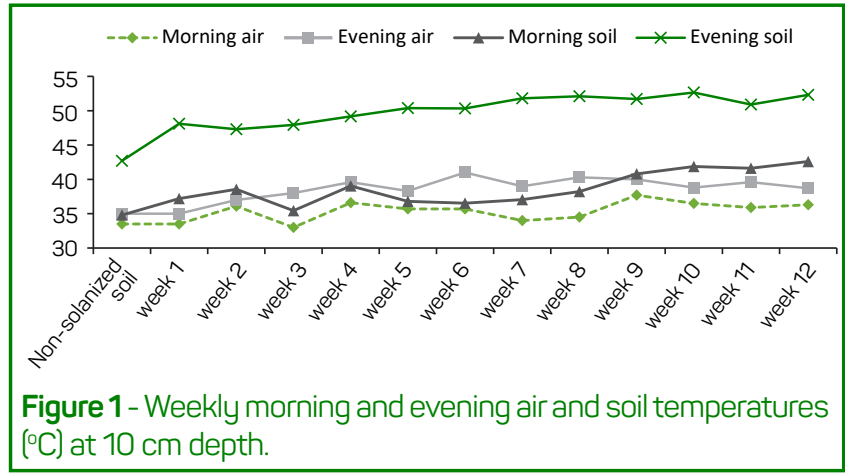

Table 1 - Effect of solarization treatments on soil NPK and organic matter contents.

\begin{tabular}{l|l|l|l|l|}
\hline $\begin{array}{l}\text { Soil solarization } \\
\text { durations (weeks } \\
\text { before sowing) }\end{array}$ & $\begin{array}{c}\text { Soil N } \\
\text { (\%) }\end{array}$ & $\begin{array}{c}\text { Soil P } \\
\text { (ppm) }\end{array}$ & $\begin{array}{c}\text { Soil K } \\
\text { (ppm) }\end{array}$ & $\begin{array}{c}\text { Soil O.M. } \\
\text { (\%) }\end{array}$ \\
\hline 0 & $0.47 \mathrm{~d}^{*}$ & $7.42 \mathrm{~d}$ & $124.8 \mathrm{e}$ & $0.92 \mathrm{c}$ \\
\hline 3 & $0.49 \mathrm{~d}$ & $7.75 \mathrm{~cd}$ & $132.5 \mathrm{~d}$ & $0.95 \mathrm{c}$ \\
\hline 6 & $0.58 \mathrm{c}$ & $8.15 \mathrm{c}$ & $144.1 \mathrm{c}$ & $1.00 \mathrm{~b}$ \\
\hline 9 & $0.62 \mathrm{~b}$ & $8.71 \mathrm{~b}$ & $154.0 \mathrm{~b}$ & $1.08 \mathrm{a}$ \\
\hline 12 & $0.71 \mathrm{a}$ & $9.63 \mathrm{a}$ & $166.1 \mathrm{a}$ & $1.12 \mathrm{a}$ \\
\hline HSD (at 5\% & 0.0320 & 0.5605 & 5.5433 & 0.0441 \\
\hline probability) & & & & \\
\hline
\end{tabular}

*Means in the same column sharing the same letter do not differ significantly at $5 \%$ probability level according to Tukey's honestly significant difference (HSD) test.

\subsection{Effect of solarization treatments on soil organic matter (\%)}

The extension in soil solarization significantly increased the soil organic matter content. The organic matter ranged from 0.92 to $1.12 \%$. The most efficient treatment in improving organic matter content was the soil solarization for 12 weeks before sowing (1.12\% of organic matter), and the second most efficient treatment in increasing organic matter content was the solarization for nine weeks before planting (1.08\% of organic matter) (Table 1 ). The untreated control showed the minimum organic matter content $(0.92 \%)$. The enhancement in soil organic matter content by prolonging the soil solarization duration was probably due to the rapid decomposition of plant residues in the soil. Bothwell et al. (2014) concluded that an increase in soil temperature effectively increased organic matter decomposition. Golzardi et al. (2015) and Khan et al. (2012) also reported an increase in organic matter by increasing the soil solarization duration.

\subsection{Efficacy of solarization treatments to control weeds in sesame}

The weed density $\mathrm{m}^{-2}$, weed biomass, and weed control efficiency were significantly affected by different soil solarization treatments (Table 2). Maximum weed density (26.75 $\mathrm{m}^{-2}$ ) was measured in the control treatment. The significant decline in weed density $\mathrm{m}^{-2}$ started from soil solarized for three weeks before sowing. Minimum weed density $\left(5.50 \mathrm{~m}^{-2}\right)$ was noted from soil solarization for 12 weeks before sowing, followed by a weed density of 8.25 as reported in soil solarization for nine weeks before sowing. Soil solarization treatments significantly affect weed biomass. By increasing the soil solarization duration from 0 to 12 weeks before sowing, weed biomass showed a gradual decline. The weeds biomass ranged from 16.50 to $46.5 \mathrm{~g} \mathrm{~m}^{-2}$. The maximum weed biomass $\left(46.5 \mathrm{~g} \mathrm{~m}^{-2}\right)$ was noted with control plots (un-solarized). Minimum weed biomass $\left(16.50 \mathrm{~g} \mathrm{~m}^{-2}\right.$ ) with maximum weed control efficiency (64.5\%) was recorded with soil solarization for 12 weeks before sowing, followed by $24.7 \mathrm{~g} \mathrm{~m}^{-2}$ weed biomass with weed control efficiency of $46.7 \%$, as observed with soil solarization for nine weeks before sowing. 
Table 2 - Effect of solarization treatments on weed control efficacy in sesame.

\begin{tabular}{|c|c|c|c|}
\hline $\begin{array}{l}\text { Soil solarization } \\
\text { durations } \\
\text { (weeks before } \\
\text { sowing) }\end{array}$ & $\begin{array}{c}\text { Weed } \\
\text { density } \\
\left(\mathrm{m}^{-2}\right)\end{array}$ & $\begin{array}{l}\text { Weed } \\
\text { biomass } \\
\left(\mathrm{g} \mathrm{m}^{-2}\right)\end{array}$ & $\begin{array}{c}\text { Weedcontrol } \\
\text { efficiency } \\
(\%)\end{array}$ \\
\hline 0 & $26.75 a^{*}$ & $46.5 a$ & \\
\hline 3 & 15.25 b & $35.75 b$ & 23.11 \\
\hline 6 & $8.50 \mathrm{c}$ & 28.25 c & 39.24 \\
\hline 9 & $8.25 \mathrm{c}$ & 24.75 c & 46.77 \\
\hline 12 & $5.50 \mathrm{c}$ & $16.50 \mathrm{~d}$ & 64.50 \\
\hline $\begin{array}{l}\text { HSD (at 5\% } \\
\text { probability) }\end{array}$ & 3.87 & 5.11 & \\
\hline
\end{tabular}

Reduction in weed density by increasing the soil solarization period was probably due to the increase in temperature to a level that decayed weed seed bank and killed germinating seedlings of most of the weeds present. Previous studies in various crops also showed that by increasing the period of polythene sheet spread on the soil surface before crop sowing, weed density was significantly reduced (Khan et al., 2003; Kumar et al., 2002; Marenco and Lustosa, 2000). Kumar and Sharma (2005) reported that $90 \%$ of Cyprus spp. were controlled by soil solarization for 32 days in potato. Up to $50 \%$ reduction in weed density by soil solarization at a depth of $5 \mathrm{~cm}$ was mentioned in carrots by Marenco and Lustosa (2000). Above $80 \%$ of weeds were controlled by solarization until the tomatoes harvest (Kumar et al., 2002). Soil solarization for two months reduced $90 \%$ weed population and increased weed control percentage with the rising duration of soil solarization in lettuce and soybean (McGovern et al., 2013).

The decline in weed biomass in response to the extension in soil solarization period before sowing was attributed to reduced weed density. Golzardi et al. (2014) described that soil solarization for six weeks before sowing was sufficient to decrease weed biomass significantly in soybean. Khan et al. (2012) and Singh (2006) also reported that weeds' biomass gradually reduced by increasing the cauliflower's soil solarization duration.

\subsection{Effect of solarization treatments on sesame and yield contributing traits}

The thermal treatments caused a significant effect on plant height, the number of capsules per plant, seed per capsule, and 1,000-seed weight of sesame (Figure 2). Soil solarization for 12 weeks before sowing caused a significant increase in plant height $(114.9 \mathrm{~cm})$, the number of capsules per plant (244.60), seed per capsule (54.95), and 1,000seed weight $(2.91 \mathrm{~g})$ of sesame as compared to shorter solarization durations (Figure 2). Control (un-solarized) treatment produced the lowest response to these traits.
By increasing the solarization durations from three to 12 weeks, the sesame growth was gradually increased. The enhancement in sesame growth and yield contributing traits by prolonging soil solarization durations might result from better vegetative growth on account of the reduction

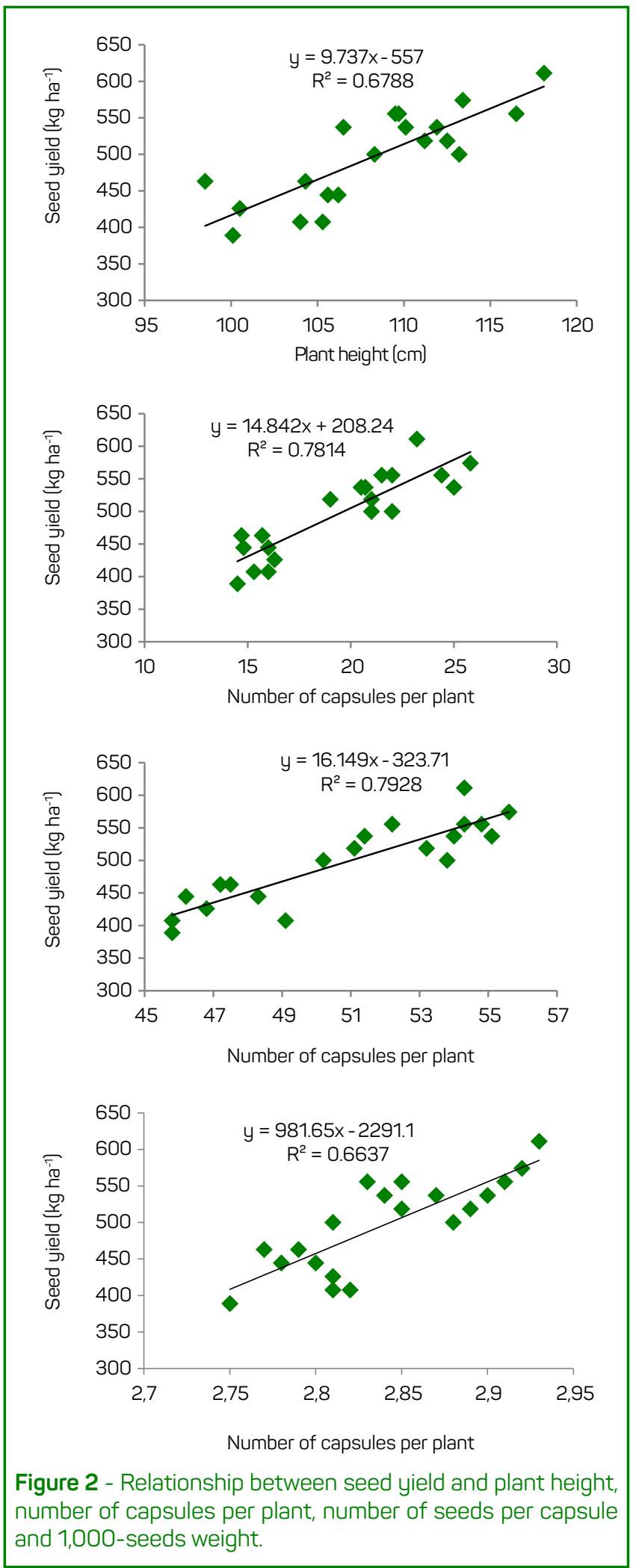


in weed infestation and improvement in soil NPK and organic matter contents. Our results are in accordance with those of Díaz-Hernández et al. (2017), who noticed that tomatoes' plant height was increased by extension in soil solarization durations. Benlioglu et al. (2005) and Gul et al. (2013) also measured significant enhancement in plant height by prolonging soil solarization with a transparent plastic sheet before sowing.

The rise in the number of capsules plant ${ }^{-1}$ of sesame from increasing solarization durations was due to the reduction in weed infestation during the flowering stage and an increase in NPK availability by soil solarization. Benlioglu et al. (2005) and Stevens et al. (1990) reported that the number of capsules per plant increased by soil solarization because solarization increased the soil fertility, which ultimately affected the yield parameters positively and increased the number of capsules per plant.

The improvement in the number of seeds capsule ${ }^{-1}$ of sesame by the extension of the soil solarization period might result from a reduction in weed density during the capsules growth stage and increased NPK availability by soil solarization. Our results are in line with Benlioglu et al. (2005) and EL-Keblawy and Al-Hamadi (2009), who reported that with increasing soil solarization duration, the number of seeds capsule ${ }^{-1}$ increased significantly.

The enhancement in 1,000-seed weight noticed by increasing soil solarization duration might result from better seed development and increased NPK availability. Díaz-Hernández et al. (2017) and McGovern et al. (2013) reported an increase in 1,000-seed weight and seed yield by prolonging the summer season's soil solarization periods.

\subsection{Effect of thermal weed control treatments on sesame yield}

Sesame biological and grain yield were gradually increased at and beyond six weeks of solarization (Table 3). The maximum biological yield (2.70 ton ha ${ }^{-1}$ ) and grain yield ( 0.57 ton ha $\left.{ }^{-1}\right)$ were produced from soil solarization

\begin{tabular}{|c|c|c|}
\hline $\begin{array}{l}\text { Soil solarization durations } \\
\text { (weeks before sowing) }\end{array}$ & $\begin{array}{l}\text { Biological yield } \\
\text { (ton ha-1) }\end{array}$ & $\begin{array}{c}\text { Seed yield } \\
\text { (ton ha-1) } \\
\text { (percentincrease) }\end{array}$ \\
\hline 0 & $2.14 d^{*}$ & $0.43 b$ \\
\hline 3 & $2.22 \mathrm{~d}$ & 0.44 b (2.35) \\
\hline 6 & $2.36 \mathrm{c}$ & 0.53 a (23.8) \\
\hline 9 & $2.50 \mathrm{~b}$ & 0.53 a (23.9) \\
\hline 12 & 2.71 a & 0.57 a (33.6) \\
\hline HSD (at 5\% probability) & 114.75 & 68.26 \\
\hline
\end{tabular}

*Means in the same column sharing the same letter do not differ significantly at 5\% probability level according to Tukey's honestly significant difference (HSD) test. for 12 weeks before sowing, followed by 2.5 ton ha ${ }^{-1}$ and 0.53 ton ha ${ }^{-1}$ under soil solarization for nine weeks before sowing, respectively. The soil solarization treatments caused up to a $33.69 \%$ increase in sesame grain yield. The minimum biological yield ( 2.1 ton ha $\left.\mathrm{a}^{-1}\right)$ and grain yield $(0.43$ ton $\mathrm{ha}^{-1}$ ) were recorded with the control (non-solarized).

The increase in biological and grain yield of sesame by extending the period of soil solarization was due to efficient weed control that reduced weed crop competition and increased growth and yield contributing traits of sesame. Our results are in the agreements with EL-Keblawy and AlHamadi (2009) and McGovern et al. (2013), who reported an increase in biological yield and seed yield in soybean by prolonging the soil solarization duration.

The positive relationship of seed yield with plant height $\left(R^{2}=0.6788\right)$, number of capsule ${ }^{-1}\left(R^{2}=0.7814\right)$, number of seeds capsule-1 $\left(R^{2}=0.7928\right)$ and 1000 -seed weight $\left(R^{2}\right.$ $=0.6637)$ indicated by regression analysis Figure (1). The current results are strengthened by Ghosh and Dolai (2014) and Khan et al. (2012), who stated that crop yield rose by increasing soil solarization durations.

\section{Conclusions}

The soil solarization treatments with polythene sheets provided effective control of weeds (up to $64 \%$ efficacy), enhanced soil fertility, soil organic matter, sesame growth, and yield (up to 34\%) under agro-ecological conditions of Punjab, Pakistan. The effect was gradually increased with an increasing solarization duration, and 12-week solarization before sowing was most effective.

\section{Author's contributions}

MES, MS, and MAN conceived the idea, conducted research, wrote abstract, methodology, did statistical analysis, conclusion, technical input at every step, and overall article management. AA, NF, and GS guide to planning research, wrote abstract, methodology, conclusion and helped to improve the article. IH, and TA make format according to journal and improvements in introduction, results and discussion and data presentation.

\section{Acknowledgements}

We acknowledge the College of Agriculture, University of Sargodha and In-Service Agricultural Training Institute for providing space, laboratory facilities and area to conduct research.

\section{Funding}

No funding source to provide financing. 


\section{References}

Abbas T, Nadeem MA, Tanveer A, Ali HH, Matloob A. Evaluation and management of acetyl-CoA carboxylase inhibitor resistant littleseed canarygrass (Pholoris minor) in Pakistan. Arch Agron Soil Sci. 2017;63(11):1613-22. Available from: https://doi.org/10.1080/03650340.2017.1296135

Alim MA. The yield performance of sesame in response to population density and source sink manipulation. Appl Bot Abstr. 2007;18:188-202.

Arbopleya J. Soil solarization on onion beds for weed and disease control in Uruguay. Colomb J Hortic Sci. 2009;3(2):223-36.

Arora A, Yaduraju NT. High-temperature effects on germination and viability of weed seeds in soil. J Agron Crop Sci. 1998;181(1):35-43. Available from: https://doi.org/10.1111/j.1439-037X.1998.tb00395.x

Asagarpour R, Ghorbani R, Kouchaki AR, Mohammadabadi AA. Effect of soil solarization on weed seed bank and soil properties. J Plant Prot. 2008-9;23(2):82-8.

Benlioglu SS, Boz Ö, Yildiz A, Kaşkavalci G, BenliDoğlu K. Alternative soil solarization treatments for the control of soil-borne diseases and weeds of strawberry in the western Anatolia of Turkey. J Phytopathol. 2005;153(7-8):423-30. Available from: https://doi.org/10.1111/j.1439-0434.2005.00995.x

Bothwell LD, Selmants PC, Giardina CP, Litton CM. Leaf litter decomposition rates increase with rising mean annual temperature in Hawaiian tropical montane wet forests. PeerJ. 2014;2:e685. Available from: https://doi.org/10.7717/peerj.685

Carles L, Joly M, Joly P. Mesotrione herbicide: efficiency, effects, and fate in the environment after 15 years of agricultural use. Clean (Weinh). 2017;45(9):1700011. Available from: https://doi.org/10.1002/clen.201700011

Díaz-Hernández S, Gallo-Llobet L, Domínguez-Correa P, Rodríguez A. Effect of repeated cycles of soil solarization and biosolarization on corky root, weeds and fruit yield in screen-house tomatoes under subtropical climate conditions in the Canary Islands. Crop Prot. 2017;94:20-7. Available from: https://doi.org/10.1016/j.cropro.2016.12.010

El-Keblawy A, Al-Hamadi F. Assessment of the differential response of weeds to soil solarization by two methods. Weed Biol Manage. 2009;9(1):72-8. Available from: https://doi.org/10.1111/j.1445-6664.2008.00320.x

Gelsomino A, Badalucco L, Landi L, Cacco G. Soil carbon, nitrogen and phosphorus dynamics as affected by solarization alone or combined with organic amendment. Plant Soil. 2006;279(1-2):307-25. Available from: https://doi.org/10.1007/s11104-005-2155-1

Ghosh P, Dolai AK. Soil solarization, an eco-physiological method of weed control. Glob J Sci Frontier Res. 2014;14(4):40-3.

Golzardi F, Vaziritabar Y, Vaziritabar Y, Asilan KS, Hasan M, Sayadi M et al. Effect of solarization and polyethylene thickness cover type on weeds seed bank and soil properties. J Appl Environ Biol Sci. 2015;5(6):88-95

Golzardi F, Vaziritabar Y, Vaziritabar Y, Sarvaramini S, Ebadi SZ. Solarization period and thickness of polyethylene sheet effects on weed density and biomass. Indian J Fundam Appl Life Sci. 2014;4(S3):587-93.
Grunzweig JM, Katan J, Ben-Tal Y, Rabinowitch HD. The role of mineral nutrients in the increased growth response of tomato plants in solarized soil. Plant Soil. 1999;206(1):21-7. Available from: https://doi.org/10.1023/A:1004321118896

Gul B, Khan IA, Hussain Z, Saeed MF. Impacts of soil solarization combined with other weed control strategies on weed management in onion nurseries. Pak J Weed Sci. 2013;19(1):101-8

ljlal Z, Tanveer A, Safdar ME, Aziz A, Ashraf M, Akhtar N, et al. Effects of weed crop competition period on weeds and yield and yield components of sesame (Sesamum indicum L.). Pak J Weed Sci Res. 2011;17(1):51-63

Khan AR, Srivastava RC, Ghorai AK, Singh SR. Efficient soil solarization for weed control in the rain-fed upland rice ecosystem. Int Agrophys. 2003;17(3):99-103.

Khan MA, Khan R, Khan H, Shah HU, Marwat KB, Amin A, et al. Soil solarization: an organic weed-management approach in cauliflower. Commun Soil Sci Plant Anal. 2012;43(13):1847-60. Available from: https://doi.org/10.1080/00103624.2012.684822

Kumar R, Sharma J. Effect of soil solarization on true potato (Solonum tuberosum L.) seed germination, seedling growth, weed population and tuber yield. Potato Res. 2005;48(1-2):15-23. Available from: https://doi.org/10.1007/BF02733678

Kumar VK, Nanjappa HV, Ramachandrappa BK. Growth, yield and economics of weed control as influenced by soil solarization in tomato. Karnataka J Agric Sci. 2002;15:682-4.

Lamont WJ. Plastics: modifying the microclimate for the production of vegetable crops. J Hortic Technol. 2005;15(3):477-81. Available from: https://doi.org/10.21273/HORTTECH.15.3.0477

Law DM, Bhavsar V, Snyder J, Mullen MD, Williams M. Evaluating solarization and cultivated fallow for Johnsongrass (Sorghum halepense) control and nitrogen cycling on an organic farm. Biol Agric Hortic. 2008;26(2):175-91. Available from: https://doi.org/10.1080/01448765.2008.9755079

Marenco FA, Lustosa DC. Soil solarization for weed control in carrot. PesqAgropec Bras. 2000;35(10):2025-32. Available from: https://doi.org/10.1590/S0100-204X2000001000014

McGovern RJ, Chaleeprom W, Chaleeprom W, McGovern P, To-anun C. Evaluation of soil solarization and amendments as production practices for lettuce and vegetable soybean in northern Thailand. Agric Technol Thail. 2013;9(7):1863-72.

Nadeem MA, Abbas T, Tanveer A, Maqbool R, Zohaib A, Shehzad MA. Glyphosate hormesis in broad-leaved weeds: a challenge for weed management. Arch Agron Soil Sci. 2017;63(3):344-51. Available from: https://doi.org/10.1080/03650340.2016.1207243

Prather TS, Stapleton JJ, Mallek SB, Ruiz TS, Elmore CL. High temperature solarization for production of weed-free container soils and potting mixes. HortTechnology. 2002;12(4):697-700. Available from: https://doi.org/10.21273/HORTTECH.12.4.697 
Sahile G, Abebe G, Al-Tawaha AM. Effect of soil solarization on orobanche soil seed bank and tomato yield in central rift valley of Ethiopia. World J Agric Sci. 2005;1(2):143-7.

Singh R. Use of soil solarization in weed management on soybean under Indian conditions. Trop Sci. 2006;46(2):70-3. Available from: https://doi.org/10.1002/ts.28

Stapleton JJ, DeVay JE. Soil solarization: a non-chemical approach for management of plant pathogens and pests. Crop Prot. 1986;5(3):1908. Available from: https://doi.org/10.1016/0261-2194(86)90101-8

Stapleton JJ, Elmore CL, DeVay JE. Solarization and biofumigation help disinfest soil. Calif Agric. 2000;54(6):42-5. Available from: https://doi.org/10.3733/ca.v054n06p42

Steel RG, Torrie JH, Dickey DA. Principles and procedures of statistics: a bio-metrical approach. 3rd ed. New York: McGraw-Hill; 1997.
Stevens C, Khan VA, Okoronkwo T, Tang AY, Wilson MA, Lu J, et al. Soil solarization and Dacthal: influence on weeds, growth, and root microflora of collards. HortScience. 1990;25(10):1260-2. Available from: https://doi.org/10.21273/HORTSCI.25.10.1260

Toan DP, Thuy-Duong TN, Anders SC, Tri MB. Morphological evaluation of sesame (Sesamum indicum L.) varieties from different origins. Aust J Crop Sci. 2010;4(7):498-504

Yan Q, Duan Z, Mao J, Li X, Dong F. Effects of root-zone temperature and N, P, and K supplies on nutrient uptake of cucumber (Cucumis sativus L.) seedlings in hydroponics. Soil Sci Plant Nutr. 2012;58(6):707-17. Available from: https://doi.org/10.1080/00380768.2012.733925 